\title{
Impairment of Lip Closure
}

National Cancer Institute

\section{Source}

National Cancer Institute. Impairment of Lip Closure. NCI Thesaurus. Code C127182.

An observation of an individual's lip closure during swallowing. 